An exhibition organized by the Science Muselum of Minnesota

in cooperation with the Peabody Museum of Archaeology and Ethnology.

Harvard University, under the Collection-Sharing Program of the Peabody Museum

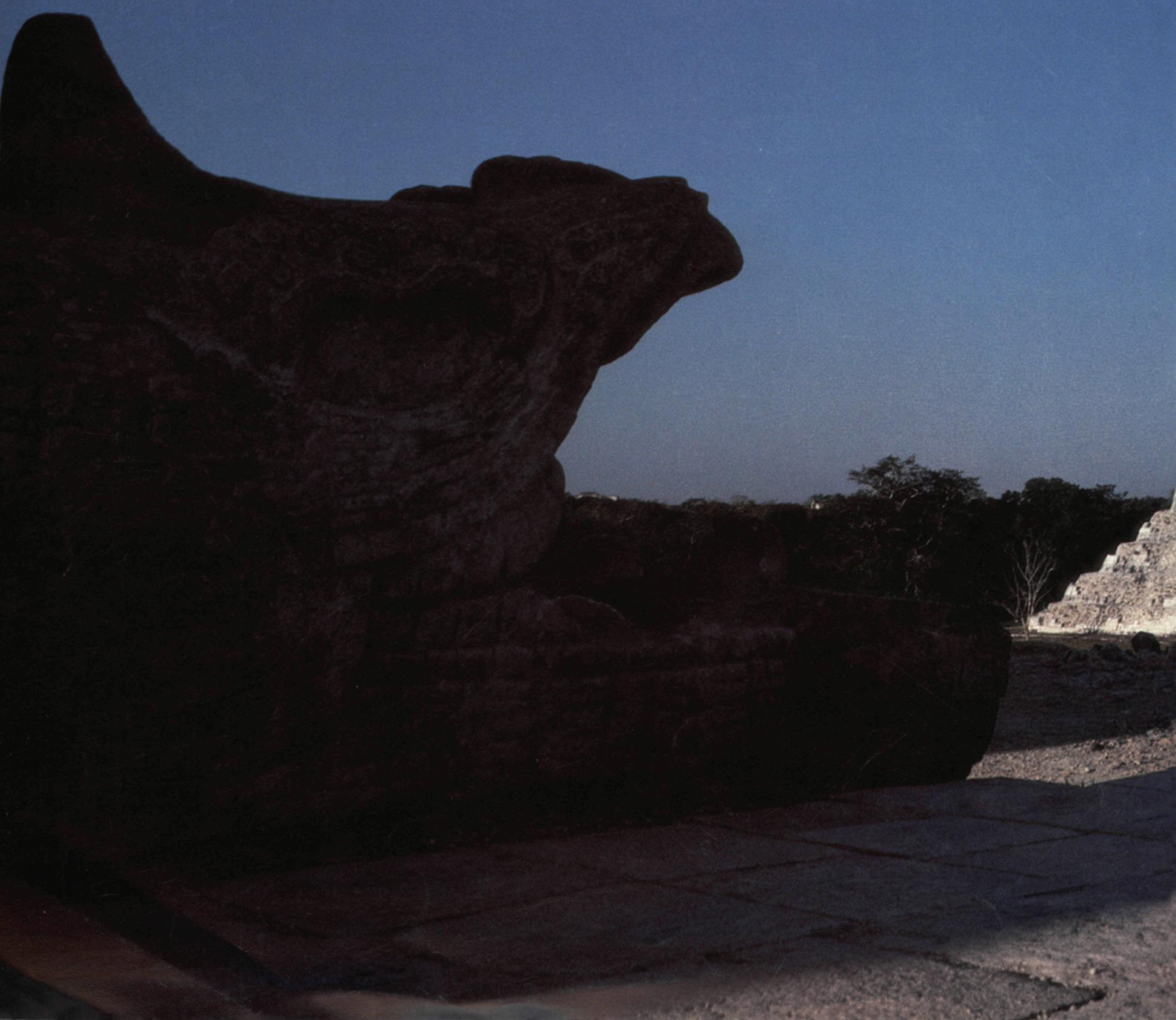




\section{Cenote of Sacrifice}

Maya Treasures from the Sacred Well at Chichén Itzá 


\section{Cenote of Sacrifice Maya Treasures from the Sacred Well at Chichén Itzá}

Edited by Clemency Chase Coggins and Orrin C. Shane III Catalogue by Clemency Chase Coggins

With contributions by Gordon R. Willey and Linnea H. Wren Forewords by C. C. Lamberg-Karlovsky and Wendell A. Mordy Photographs by Hillel Burger

\section{$4 \rightarrow$ University of Texas Press Austin}

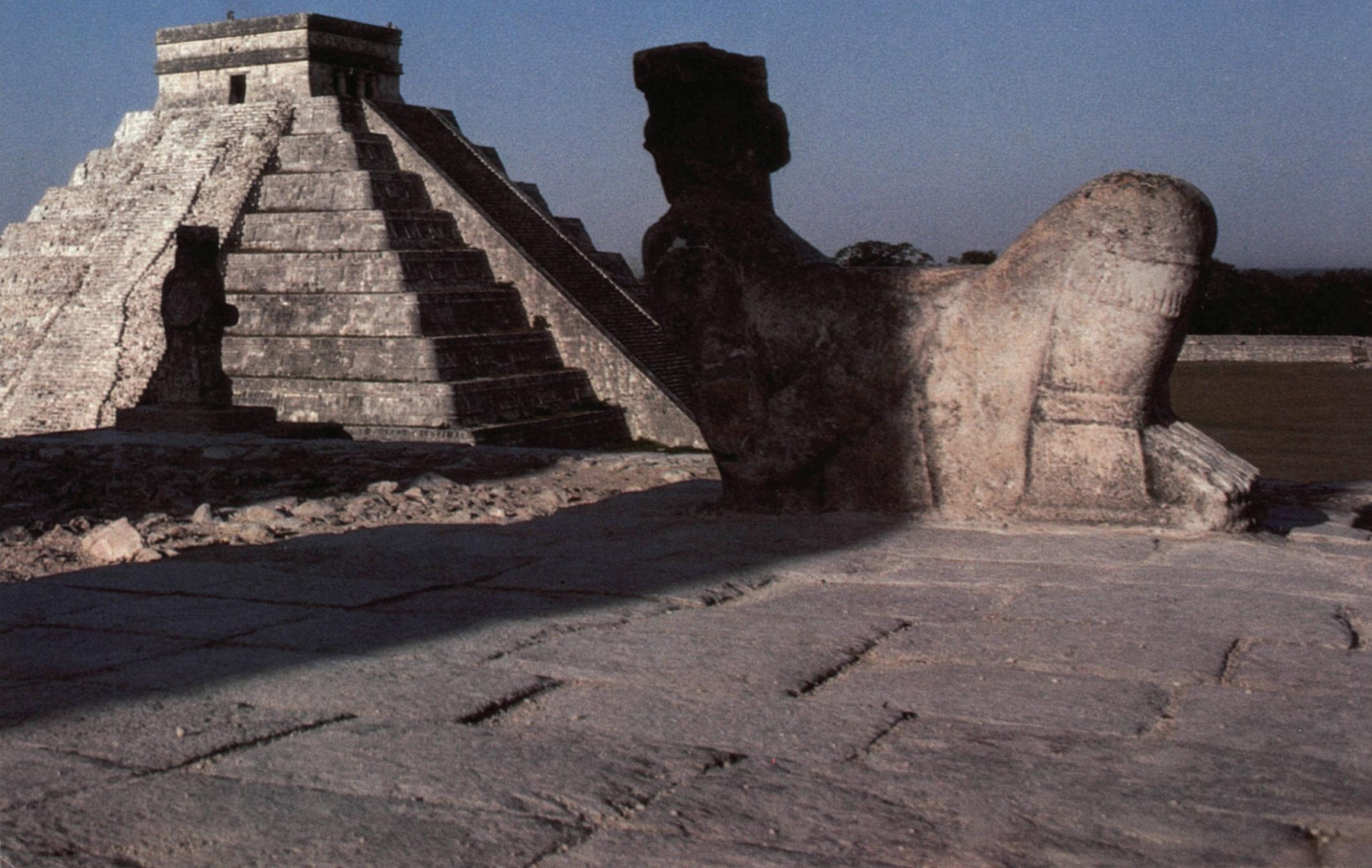


Copyright (C) 1984

by the University of Texas Press

Photographs copyright (C) 1983, 1984, by the

President and Fellows of Harvard College

All rights reserved

Printed in the United States of America

by The Whitley Company, Austin, Texas

\section{LIBRARY OF CONGRESS}

CATALOGING IN PUBLICATION DATA

Main entry under title:

Cenote of sacrifice.

Catalogue of an exhibition organized by the Science Museum of Minnesota in cooperation with the Peabody Museum of Archaeology and Ethnology, Harvard University.

Bibliography: $p$.

Includes index.

I. Chichén Itzá (Mexico)—Exhibitions.

2. Mayas-Antiquities-Exhibitions.

3. Indians of Mexico-Yucatán-Antiq-

uities-Exhibitions. 4. Peabody Museum of

Archaeology and Ethnology-Exhibitions.

I. Coggins, Clemency. II. Shane, Orrin C.

1939- . III. Science Museum of Min-

nesota. IV. Peabody Museum of Archaeology and Ethnology.

FI435. I.C5C46 I984 972'.OI 84 -IO458

ISBN 0-292-71097-6

ISBN 0-292-7IO98-4 (pbk.)

Figures $6,7, I_{0}, I_{2}, 1_{3}$, and 14 are reprinted from S. K. Lothrop I952 and Figures 8, 9, II, and 15 from T. Proskouriakoff 1974 , all by permission of the Peabody Museum, Harvard University.

Frontispiece.

Chichén Itzá: the Castillo as seen from the entrance to the Temple of the Warriors. Photograph by Jeffrey Jay Foxx.
The Collection-Sharing Program of the Peabody Museum is a unique loan program for developing collaborative exhibitions. Since the Peabody Museum's facilities do not permit the full in-house exhibition of its vast archaeological and ethnographic collections, this program enables audiences nationwide to enjoy them. The Peabody Museum CollectionSharing Program has been generously supported by the National Endowment for the Humanities. 